\title{
23 Senior-oriented empirical research in nursing homes for the elderly
}

\author{
Experiences from Austria
}

\author{
Renate Kränzl-Nagl and Daniela Wetzelhütter
}

\begin{abstract}
Despite the increase in studies on the quality of life among senior citizens in nursing homes so far only a small number have shed further light on the practical aspects of carrying out empirical surveys in these institutions. Based on experience with empirical research in Austrian nursing homes and the theoretical approach developed by Ackermann (2005), the steps in the research process are presented and discussed in this chapter, looking into the factors which may influence the research findings. It has become clear that the results of such investigations are affected by many factors, which all have to be taken into account both when planning the research and when carrying it out. These include features specific to the organization of nursing homes and to the target group, i.e., elderly people in need of care. Methodologically, the problems caused by the target group's cognitive impairments are of particular significance. In general, experience shows that is possible to carry out empirical surveys with nursing home residents, although they do place relatively high demands on researchers. Another lesson learned is that studies should be carried out taking other perspectives into account - especially those of the relatives and nursing staff - to gain a full picture of nursing home residents' quality of life. Another point which has become very clear is that close cooperation between the researchers and the nursing home's management and nursing staff plays a key role in the success of such projects.
\end{abstract}

\section{Introduction}

For a long time, relatively little importance was attached to research on care home residents' quality of life (European Centre for Social Welfare Policy and Research, 2010, p. 19). This was not only true of German-speaking countries. This circumstance is explained by the strong focus on the traditional topics related to the quality of care and associated with that - a certain hostility toward research and measurement among those committed to improving elderly people's quality of life (Kane, 2001, 2003). Since the 1990 s, there has been a rise in the amount of research not only carrying out evidence-based examinations of the quality of care and nursing but also dealing with quality of life among elderly people in need of support and care (e.g., Albrecht, 1997; Lee, Woo and MacKenzie, 2002; Schnabel and Schönberg, 2003; Gelbmann, 2005; Schönberg, 2006; Wahl and Schneekloth, 2009; ZeSG, 2010; Herold-Majumdar and Behrens, 2012). Recent studies measuring the impact of social services have now also begun to address this topic (KränzlNagl, Lehner and Prinz, 2019). Other factors which have led research to focus more sharply on elderly people's situation in life include the increasing customer focus found in social services for senior citizens and the need for evidence-based data when implementing 
quality management and quality assurance techniques in homes for the elderly. This is related to efforts to take elderly people seriously as subjects of research, and to include them in empirical surveys.

In methodological terms, this endeavor has shown that surveys on the situation of people in need of care pose specific challenges in the residential context. On one hand this relates to the particular characteristics of the target group, senior citizens; on the other hand, it is linked to the very specific conditions found in nursing homes, which are both the place where elderly people live and are cared for, and the nursing staff's workplace.

With this in mind, this contribution addresses the question of how empirical surveys can be fitted into the structures and processes of a nursing home and what factors influence such surveys (the next section of this chapter). This will involve taking a closer look at the characteristics specific to care home residents, as a target group, as these characteristics are methodologically relevant in many respects (the third section of the chapter). The chapter then sets out how the research process is structured in empirical studies in residential institutions, involving both residents and their relatives. This section draws upon experiences from Austrian research practice. At each stage of this process, a connection will be made to the influencing factors described at the start. The contribution is rounded off with a final summary.

\section{Empirical surveys in nursing homes: overview of influencing factors}

Empirical findings collected in different care and nursing settings are influenced by a variety of factors. This can be conceptualized using the model Ackermann (2005) designed for empirical studies with care home residents in field experiments. This is presented and reflected upon in greater detail below in the context of nursing homes in Austria.

\section{Ackerman's model of factors influencing empirical studies in nursing homes (2005)}

According to Ackermann (2005, p. 96f.), the factors influencing empirical research into the perspective of care home residents can be divided into four groups:

1 influences of the research setting (structural conditions);

2 influences of the residents as the "object of investigation";

3 influences of the researcher's presence;

4 influences of the research design and selected method.

As Figure 23.1 illustrates, these factors do not exist independently of each other, but instead influence one other - a circumstance that has to be taken into account both when planning and when implementing empirical surveys in the field of care for the elderly. The model thus shows parallels to the "total survey error" (TSE) concept, which places the emphasis on assessing the errors which can influence the survey findings. This concept (Biemer, 2010a; Biemer and Lyberg, 2003) convincingly demonstrates that, when assessing the quality of a survey, it should be remembered that there is already a likelihood of potential "errors" being committed when the research concept is being planned, and that this possibility does not fade away when the data is prepared, but in fact lasts at least until it is analyzed. In other words, although the total survey error is made up of sampling and non-sampling errors (Biemer and Lyberg, 2003; Weichbold, 2008, 2009), it is not measured 


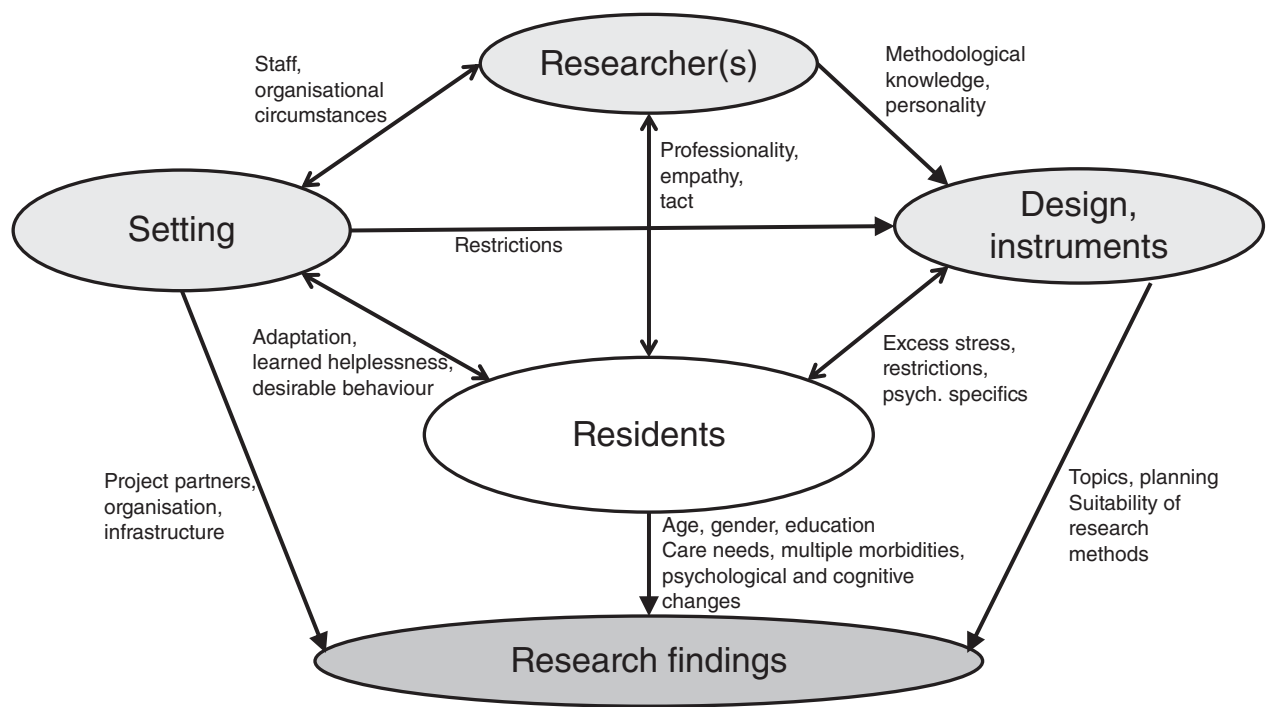

Figure 23.1 Model of factors influencing empirical research with nursing home residents in field experiments.

Source: taken from Ackermann, 2005, p. 96; the author's own translation.

as the sum of individual aspects or criteria (Biemer 2010b). Rather, the concept of total survey error is an attempt to describe the errors occurring within a logical sequence of individual steps of a "whole" process (Groves et al., 2004).

The influencing factors which fall into the category of the survey setting comprise the basic structural conditions in which a survey is taking place, and which may affect the findings (Ackermann, 2005, p. 96). These include a home's human and material resources, architectural structures, the staff's training level and the home's internal organizational structures and processes (mealtimes, rest periods, doctors doing their rounds, internal events, organized activities etc.). These factors are examined to ascertain the quality of these structures and processes; in combination with empirical investigations into the quality of the findings, this helps paint an overall picture. When carrying out surveys of nursing home residents, researchers from outside the home must necessarily familiarize themselves with these structural conditions, ideally even at the planning stage. The specific rooms in which the survey takes place can, for example, influence the findings.

The values and norms fostered by an institution or provider, e.g., those set out in mission statements, are also relevant to empirical surveys. An organizational culture driven by and, what is more, practicing - appreciation and a sense of customer focus can create a climate in the home which also suits the needs of empirical research. One important factor contributing to the success of empirical surveys by external researchers is whether or not they become familiar with the particular care setting, enabling them to make decisions relevant to the survey. In this context, the support they receive from the management and nursing staff at the home plays an important role. Ackermann (2005, p. 96) also includes staff support for the survey in this set of factors; their support relies on timely internal information and motivation, especially on the part of management. 
The second set of factors relates to the influences exerted by the residents as the "object of investigation", i.e., the particular characteristics displayed by the target group of old people in need of help and care. This is by no means a homogeneous group; instead, its members display specific characteristics including the state of their health, their cognitive and functional ability and mental factors such as their attitudes or values, which have to be taken into consideration throughout the research process (Ackermann, 2005, p. 96). On one hand, the characteristics of this target group influence the selection of the survey instruments and the interpretation of the data gathered. On the other hand, they affect the respondents' motivation or how open they are to empirical research (for further details, see next section). This can be encouraged by providing information at an early stage and arranging trust-building and motivating schemes.

The influences of the researcher's presence comprise the classical "experimenter effects" (Ackermann, 2005, p. 97) such as their professional background, qualifications, previous experience, methodological skills, internal psychological factors and personality traits. One especially important aspect influencing the success of studies in the field of care for the elderly is the methodological skills which play a key role not just in developing but also in applying the survey instruments. Experience has shown that this is especially true of oral interviews with elderly people, which require a high degree of sensibility, empathy and patience, and the creation of an atmosphere characterized by trust, respect and appreciation. This, in turn, demonstrates how important personal skills, especially social skills, are to the success of empirical surveys. Accordingly, the aim must be to select research staff specifically in line with these requirements and to offer them continuing education and training in these fields. Interviewer training is another means of reducing experimenter effects.

Finally, the research design and selected method affect the outcome of a study; they also have a decisive influence on the research process and thus the course of the investigation (Ackermann, 2005, p. 97). The decisions which have to be made when formulating the research design (choice of facilities, methodological approach, frequency of surveys, etc.) do not only serve to precisely define the project; they also take into account the abovementioned structural framework of the care setting, and the target group.

In this context, one factor which is particularly significant is making a suitable choice of method based on the goals of the study, the special features of the clients in question and, ultimately, the available financial resources. Thus, a relatively small project budget speaks against the use of multiple methods or instruments, however desirable that may be in many cases. In this field of research, as elsewhere, project planning and design are caught in a tug of war between people's interests and the available resources. Apart from funding, the contribution made by organizations running nursing homes lies in internally defining and specifying the goals, and how the research is expected to benefit the organization, at an early stage in the process. The resulting findings and knowledge of the structural conditions allow scientific experts to formulate a suitable research design and select which methods to use.

As well as methodological aspects such as the above-mentioned "TSE", Ackermann's model (2005) also reveals theoretical connections that are relevant when studying the views held by nursing home residents. This relates, for example, to concepts for studying quality of life based on the two classical dimensions of subjective and objective indicators. Objective indicators relate to people's situation in life and thus to the underlying structural conditions of life in nursing homes for the elderly, whereas subjective indicators focus on assessing those situations in life, i.e., people's individual perception and assessment of quality of life (Noll, 2007; Wahl and Schneekloth, 2009; Koller et al., 2009). 
From an empirical point of view, if those two perspectives match ("good" objective conditions and a high rating from a subjective, individual point of view), this can be seen as high quality of life, whereas quality of life is not as good if one of the two components is less positive. However, empirical surveys of elderly people indicate that there is often only a tenuous connection between objective and subjective quality of life. One explanation for this comes from the "paradox of ageing" (Mayring, 1987, quoted by the European Centre for Social Welfare Policy and Research, 2010, 18), according to which elderly people exhibit a particularly high level of subjective satisfaction with their lives as their objective resources wane. The question remains unanswered of the extent to which this will be true of subsequent generations. Nonetheless, the paradox of ageing indicates that the classical dimensions of research into quality of life research cannot simply be transposed unquestioningly to elderly people (see Noll and Schöb, 2002; von dem Knesebeck et al., 2006). These insights raise the question of whether people in care homes exhibit any other special features that are relevant for empirical research.

\section{Features specific to nursing home residents as a target group in empirical surveys}

The characteristics specific to the target group of elderly people which need to be taken into account when planning research and selecting a research method consist in the agerelated sensory, functional and cognitive impairments of varying levels, the occurrence of which can be subject to change (e.g., fluctuations in their condition from one day to the next).

Rising life expectancies and the trend of preferring non-residential to residential care (for as long as possible) mean that Austrian nursing homes are tending to accommodate increasingly aged residents, often with multiple morbidities. In addition, an increase has been noted for many years in the number of people suffering from forms of dementia. Estimates by the Austrian Ministry of Health and Women's Affairs (Bundesministerium für Frauen und Gesundheit, 2017) suggest that 115,000 to 130,000 people living in Austria currently have some form of dementia. According to projections, by 2050 that number will have increased to 260,000 people with dementia (Höfler et al., 2015). These developments are also changing the resident structure in nursing homes, with the percentage of residents suffering from dementia increasing.

One key characteristic of elderly people in need of care and nursing is the fact that they are in the "fourth age" of life (Laslett, 1995, quoted in Kösler, 2004). That fourth age brings with it a drop in their strength, resources and abilities, and is thus usually characterized by increasing need for support.

Another feature specific to this target group is the influence of their individual biography, which is shaped by the respective historical background of their times, and thus also by "historical" values and norms, as well as by their subjective experience of biographically relevant events. This can, for example, affect how the target group behaves when they are being interviewed or observed. In particular, it may result in response bias effects such as social desirability or a tendency to yea-say.

Negative images of elderly people which are prevalent in contemporary society (e.g., see Wahle, 2009) can also lead to lower self-esteem, which can be reflected in a humble attitude among senior citizens and a lowering of their expectations. As experiences of qualitative interviews with elderly people show, in some cases this is reflected in extreme cautiousness about expressing wishes, concerns and criticism. In such cases, social desirability 
also has an effect in that the people interviewed express opinions which are in line with other people's expectations, e.g., those of the nursing staff (see also Janßen et al., 2003, cited in Kannonier-Finster and Ziegler, 2008).

The features specific to the target group of elderly people in need of care cannot be solely ascribed to individual, personal characteristics; instead, they correspond closely with the elderly people's living conditions. In the case of nursing home residents, this means the particular institutional characteristics of their care setting. One point which should be taken into account, for example, is that as well as impaired health, another reason for a move into a residential institution may be a lack of social networks, e.g., due to increasing social isolation in the fourth age (Hicks, 2000). This circumstance means that clients are more strongly attached to, or dependent on, the staff. When people reach the fourth age, this increases their dependency both on other people and on predetermined structures and processes.

This dependent relationship must accordingly be noted as a feature specific to nursing home residents, and taken into account during surveys. Although nursing homes are increasingly opening up to their surroundings, and efforts are being made to reduce to a minimum the formal rules which might have a negative effect on residents' quality of life, they can still be described as "moderate total institutions" (Gebert and Kneubühler, 2003), and some central characteristics of the total institutions described by Goffman (1973; see also Heinzelmann, 2004) remain valid. These include both the fact that the residents have to act out every aspect of their lives within the institution and that these institutions have the authority to determine the main norms and rules which specify how people live together in this non-voluntarily formed community. It is still typical for nursing homes to comprise two different social and cultural worlds: that of the residents and that of the staff. The point should thus not be forgotten that there is a relationship of mutual dependency between the two groups which can result in a fear of sanctions on the part of nursing staff, which in turn may influence the outcome of the research. People living in homes may also fear sanctions on the part of their fellow residents. The relationship of mutual dependency between the residents and staff can, for instance, have a negative effect on people's motivation to participate or how they respond to surveys. On the other hand, precisely this close personal relationship can be used to motivate elderly people to take part in surveys, meaning that there can also be positive effects.

\section{Planning and carrying out empirical surveys in care homes for the elderly: experiences from practice}

Despite the increase in studies on the quality of life among senior citizens in nursing homes, so far only a small number have shed further light on the practical aspects of carrying out empirical surveys in these institutions (e.g., Höwer, 2002; Schönberg, 2006; Roth, Rester and Seeberger, 2009; Kränzl-Nagl and Maun, 2013). On the basis of experience with empirical research in Austrian nursing homes, the individual steps in the research process (e.g., see Kromrey, 2006; Schnell, Hill and Esser, 2006; Atteslander, 2008; Diekmann, 2008) are presented below, looking into the factors which may influence the research findings, as described above. Particular attention is paid to how such projects are supported by management and nursing staff, as this has proven to be a key success factor. The level of support required varies over the different stages of the research process, from the planning stage to making use of the findings. 


\section{Planning and preparation stage}

Whatever methodological approach is selected to assess quality of life and satisfaction among nursing home residents, a series of decisions are required even at the planning stage which are crucial to the success of an empirical survey in different care and nursing settings. These include establishing precise objectives, settling on the basic conditions and data protection issues, addressing how to use the findings, choosing a specific survey design, gathering important information and finally announcing the project to residents, their relatives and the nursing staff.

\section{Establishing precise objectives}

One of the first, important steps proves to be settling on and narrowing down the goals of the survey. This is carried out jointly by the principal investigators and the nursing home management (if possible also involving the organization running the home). At this stage, agreeing upon the survey's purpose from the point of view of the organization or institution (e.g., in terms of strategic processes or marketing) is just as important as how the content of the project relates to the organization's mission statement. Another point which needs to be agreed upon is the researchers' specific interests. These are connected to the project goals. Defining objectives thus means reconciling the researchers' academically oriented viewpoints with those of the practice-oriented executives; ideally, these potentially different viewpoints will complement one another. Establishing the objectives of the planned research at as early a stage as possible also encourages the client to identify with the aims of the study. This identification can then be passed on to other levels of the organization, especially the nursing staff. In addition, establishing the specifics at this early stage means that targeted information about the project can be provided early on.

\section{Settling on the basic conditions}

Another important step is to clarify the basic conditions in which the investigation is to be carried out. Generally, this includes the care concept and aspects related to the schedule, location, organization and financing, which differ from one nursing home to another. Sorting out the organizational aspects involves on one hand adapting the investigation to the home's structures and processes, and on the other hand the question of how the management and staff will support the project. Crucial prerequisites include selecting communication channels and contact people, drawing up a realistic timetable and agreeing upon responsibilities.

\section{Settling data protection issues}

Data protection issues also need to be settled in the lead-up to research. This comprises access to and handling of the personal data required to conduct the empirical research (e.g., a list of all residents as the basis for sampling). When carrying out surveys, appropriate steps must be taken with regard to current data protection law (in Austria the General Data Protection Regulation, GDPR). As well as complying with the data protection rules regarding available data, maintaining anonymity and treating newly gathered data (e.g., from surveys) as confidential is a basic principle of research ethics, as is making participation in surveys voluntary. In the case of elderly people who are no longer able to give 
consent due to impairments, consent must be sought from their relatives or other representatives. This must be informed consent, i.e., they must both be willing to take part and have been informed about the planned investigation (Bortz and Döring, 1995, p. 43).

\section{Using the findings: explanation and information}

It is very important for everyone involved to be told how the findings will be used, even at this very early stage. This is not only designed to increase their motivation and support, but is ultimately a question of research ethics. This does not just mean aspects of appreciation and respect (which are guiding principles when conducting surveys) but should also be expressed in the subjects being given feedback about the findings. On the part of the management, the decision must be made as to when and in what form the residents and their relatives will receive feedback on the empirical findings.

Experience shows that the decision on whether the findings are to be made accessible to the broader public (e.g., providing abstracts online) is made at a later date. As new findings are not only useful in practice but are also intended to drive academic discourse, it makes sense to establish whether the findings can be used for scientific purposes at an early stage.

\section{Choosing a specific survey design - information required}

Based on the objectives and basic conditions which have been established, the next step lies in choosing a research design. This task falls to the researchers due to their specific expertise, and involves selecting the method or methods (if several are used), the target group to be surveyed and the selection process to be applied, etc.

In this regard, it is important to cooperate with the home's management so as to gain internal information relevant to the project. If, for example, surveys are planned, the question must be resolved beforehand of which people, or how many, can take part in the survey. On one hand, this provides information about the population and is thus a prerequisite for sampling (if planned); on the other hand, the information about the elderly people can be used to develop the survey instruments, such as questionnaires or guidelines for qualitative surveys. If people suffering from dementia are to be included in the investigation, and observation methods are to be used, this also requires more detailed information about these people (e.g., the degree of dementia, biographical details). As a word of caution, the decision on who should be included in the investigation should not be left to the institution. This leads to an arbitrary selection which in turn can influence the study findings. This effect can be counteracted by developing criteria for staff to evaluate, e.g., whether people can take part in a survey, or other selection criteria. Under data protection law, anonymity must always be guaranteed.

Once the details of the research design are sufficiently specific, it should be presented to the management. Experience from practice shows that transparent planning and effective communication between the researchers and management are important factors affecting whether surveys can successfully be conducted in nursing homes.

\section{Announcing the project: transparency thanks to information}

The next step should be to announce the project in a timely manner within the organization, i.e., both to the nursing staff (including volunteers) and to the residents and their relatives. The more clearly and transparently the goals of an empirical survey and the support which 
is expected are expressed, the greater everyone's motivation to take part. At this point, it is important for the research team to make personal contact with the staff, the residents and their relatives at an early stage, mainly so as to avoid any of the possible adverse effects related to an external evaluation (e.g., reservations, uncertainty and fears) from the start.

When presenting the planned investigation to the residents, it is important to insure that the information is introduced in an age-appropriate manner, not only to the people in care but also to their relatives, who are often themselves also elderly (e.g., partners). Involving them at an early stage can be seen as one aspect of work with relatives, which has become increasingly important in the field of care for the elderly (e.g., see Engels and Pfeuffer, 2007).

\section{Developing and using the survey instruments}

In line with the research design, which sets out the research approach (quantitative or qualitative), methods (survey, observation, etc.) and instruments (questionnaires, interview guidelines etc.), the next step is for the research team to develop those instruments.

For the operationalization process, it is not only important to be familiar with relevant specialist literature; the use of explorative, qualitative methods is also recommended (Flick, 2006). To complement the information about the organization and residents, explorative preliminary studies provide information which is valuable when developing further instruments.

Although it is now generally agreed that elderly people are able to take part in surveys (Lage, 1999), the choice of method hinges on the level of any cognitive impairment. If the decision is made in favor of a survey then, when developing the instruments, the question must be asked what cognitive tasks the respondents can be expected to perform, as indicated by cognitive response theory (Groves et al., 2004). According to this, answering a question takes four steps: (i) comprehension of the question, (ii) recall and retrieval of relevant information, (iii) judgment and estimation based on the retrieved information and (iv) reporting an answer by linking it to the response category provided (see Groves, 2004, pp. $202 \mathrm{ff}$.).

Studies in which surveys were carried out with elderly people show that it is especially important to design the instruments in a "senior-friendly" way (re the opportunities and limits of resident surveys, see e.g., Höwer, 2002; Schönberg, 2006). If questionnaires are used, it should be insured that they are not too long and are written in a large font, with a clear, attractive layout and precisely formulated, clear questions which are not too long or complex. They should also include instructions so that the elderly people can easily fill them in on their own, as is usually the expectation. If, on the other hand, the plan is for the questionnaire to be filled in with the help of an interviewer, appointments are to be made which fit in with the daily routine or schedule at the home. Generally, a pre-test should be carried out to check whether the instrument is "senior-friendly".

Qualitative surveys involving oral, loosely structured interviews are generally carried out by the researchers themselves. Such interviews typically take place in a familiar environment, i.e., the nursing home. Experience has shown that this requires plenty of time to be scheduled, and the respondents' daily routine needs to be taken into account. The limits of such interviews become apparent when respondents show signs of fatigue, or physical or psychological factors indicate that the interview should be discontinued and, if appropriate, resumed later. Cases of this kind should be taken into account beforehand, in terms both of organization and the amount of time planned. In addition to this, oral surveys 
with elderly people require the interviewers to be extremely empathic, sensitive, patient and flexible when conducting the interview. In this respect, it is productive to train the interviewers and test the interview guidelines in advance.

The interview situation itself is also an important factor which can influence findings. When conducting oral surveys in homes, for example, it should generally be insured that the atmosphere is peaceful and familiar. In the case of quantitative surveys, there is often no control over the interview situation, as the questionnaire is usually completed in the researchers' absence. This can prove problematic if nursing staff are asked to help complete the questionnaire and thus influence the way the respondents answer. To avoid effects of this kind, it is constructive to provide information about the survey and what staff should do if this happens. Methodologically, even with quantitative surveys it is advisable to use face-to-face interviews in nursing homes, although these usually incur considerable costs.

Whichever method is used, if researchers are not carrying out the interviews themselves, or if questionnaires need to be given to residents, researchers depend on the support of staff, who can offer significant help with organizing surveys thanks to being in permanent contact with elderly people. Getting the questionnaires back is slightly trickier. To maintain anonymity, one tactic which has proven successful is to hand out the questionnaires in sealed envelopes, which are collected by the staff. Another option is to set up boxes into which residents post the completed questionnaires, which are then collected by the researchers after the response period is over.

One method which is generally not recommended, by contrast, is for the nursing staff to survey the residents, due to the expected effects this would have on how the senior citizens respond. It would also not be reasonable due to the time required, especially as staff in residential care for the elderly have a high workload as it is (see Stadtler, 2009; Nienhaus, Westermann and Kuhnert, 2012; Dietrich, Kirch and Rößler, 2014).

In the case of people in need of care who are suffering from dementia, there are clear limits to any survey due to their cognitive impairment. As a result, a survey method is required which can measure quality of life among this group of people who are generally considered unable to respond to surveys. Here, observational techniques have proven their worth; above all, the Heidelberg instrument to measure quality of life with dementia, "H.I.L.D.E." (Becker et al., 2005) and the non-participant observation method of Dementia Care Mapping (DCM) (Innes, 2004; Müller-Hergl, 2008) are worth special mention. Observational methods can also be used with residents not suffering from dementia, e.g., in addition to surveys. As homes are more or less self-contained systems, non-participant observation methods would appear more difficult to apply than participant observation, during which researchers can interact with the residents.

\section{Evaluating and preparing the data}

The task of evaluating the data collected falls to the research team; for this reason, the management are not involved in this phase of the research process. It does, however, appear advisable to hold occasional meetings with executives, on one hand to discuss interim findings together and on the other hand so that the management can help settle unresolved interpretation issues, based on their internal knowledge. In addition, discussing the findings is an important step in developing corresponding recommendations. In this regard, it has proven worthwhile to carry out "findings workshops" involving the researchers and, ideally, representatives of different management levels. 


\section{Provision of the findings}

The question of how the residents, their relatives and the institution staff will be given feedback on the findings made should be considered from the beginning. In practice, a step-by-step approach has proved successful in this respect: first, the findings are presented in a small, internal circle of executives, next the findings and conclusions are jointly presented to all the employees internally, and only after that are the findings presented to the residents and their relatives (e.g., at family evenings).

This consists not only in presenting the empirical results but also in setting out the subsequent steps and measures resulting from them. The implications of the investigation are not only of interest to the residents and their relatives, but also, especially, to the nursing staff. Accordingly, suitable structures are needed to engage with the findings and the measures to be derived from them. For example, plans for improvement and strategies to implement them could be developed in small working groups. Meanwhile, announcing the findings and the next steps to be taken is a means of raising internal acceptance of such measures.

Finally, the decision must be made as to whether, and how, the findings are to be announced to the public at large, leading to corresponding activities such as press conferences, articles in various journals, lectures, etc.

\section{Conclusions}

Empirical surveys of nursing home residents, which typically record the subjective views, needs and requirements of elderly people as clients, provide valuable, evidence-based data for quality management and quality assurance in residential institutions. Although a rising number of studies deal with quality of life among nursing home residents, only a small number examine the practical aspects of research in any detail.

This contribution focused on the planning and implementation of empirical surveys in nursing homes based on experience gathered from Austrian research projects. One point which has become clear is that the results of such investigations are affected by many factors, which all have to be taken into account both when planning the research and when carrying it out. These include features specific to the organization of nursing homes and to the target group, i.e., elderly people in need of care. Methodologically, the problems caused by the target group's cognitive impairments are of particular significance. In general, experience shows that is possible to carry out empirical surveys with nursing home residents, although they do place relatively high demands on researchers. One recommendation which can certainly be made is that studies should be carried out taking other perspectives into account - especially those of the relatives and nursing staff - to gain a full picture of nursing home residents' quality of life. Another point which has become very clear is that close cooperation between the researchers and the nursing home's management and nursing staff plays a key role in the success of such projects.

\section{References}

Ackermann, A. (2005). Empirische Untersuchungen in der stationären Altenhilfe: Relevanz und methodische Besonderheiten der gerontologischen Interventionsforschung mit Pflegeheimbewohnern. Vol. 4. Erlanger Beiträge zur Gerontologie. Berlin and Münster: Lit.

Albrecht, P-G. (1997). Leben im Altenheim. Frankfurt am Main: Lit Verlag.

Atteslander, P. (2008). Methoden der empirischen Sozialforschung. 12th ed. Berlin: Schmidt. 
Becker, S., Kruse, A., Schröder, J. and Seidle, U. (2005). Das Heidelberger Instrument zur Erfassung von Lebensqualität bei Demenz (H.I.L.D.E.). Zeitschrift für Gerontologie und Geriatrie, 38, 108-121. Available at: www.nar.uni-heidelberg.de/pdf/newsletter/nl1_09_becker_etal.pdf[Accessed 5 September 2012].

Biemer, P.P. (2010a). Overview of design issues: total survey error. In: P.V. Marsden and J.D. Wright (eds), Handbook of survey research. Bingley, UK: Emerald Group Publishing Ltd.

Biemer, P.P. (2010b). Total survey error: design, implementation, and evaluation. Public Opinion Quarterly, 74(5), 817-848. doi.org/10.1093/poq/nfq058.

Biemer, P.P. and Lyberg, L.E. (2003). Introduction to survey quality. Hoboken, NJ: John Wiley \& Sons, Inc.

Bortz, J. and Döring, N. (1995). Forschungsmethoden und Evaluation für Sozialwissenschafter. 2nd ed. Berlin: Springer Verlag.

Bundesministerium für Frauen und Gesundheit (2017). Gut leben mit Demenz. Available at: www. bmgf.gv.at/home/Gesundheit/Krankheiten/Demenz/ [Accessed 15 December 2017].

Diekmann, A. (2008). Empirische Sozialforschung: Grundlagen, Methoden, Anwendungen. 19th ed. Reinbek b. Hamburg: Rowohlt.

Dietrich, U., Kirch, W. and Rößler, M. (2014). Arbeitsbelastungen in der stationären Altenpflege unter besonderer Berücksichtigung der Pflege dementer Menschen: Betriebliches Gesundheitsmanagement zur Stärkung der Gesundheitspotentiale von Pflegekräften. Gesundheitswesen, 76, A36. Available at: www.thieme-connect.com/products/ejournals/abstract/10.1055/s-0034-1386886\#abstract [Accessed 19 January 2018].

Engels, D. and Pfeuffer, F. (2007). Die Einbeziehung von Angehörigen und Freiwilligen in die Pflege und Betreuung in Einrichtungen. Cologne: Institut für Sozialforschung und Gesellschaftspolitik (ISG). Available at: www.isg-institut.de/download/ISGBericht\%20MuG4.pdf [Accessed 14 August 2012].

European Centre for Social Welfare Policy and Research (ed.) (2010). Verbesserung messen: Ergebnisorientierte Qualitätsindikatoren für Alten- und Pflegeheime. Vienna: European Centre for Social Welfare Policy and Research.

Flick, U. (2006). Qualitative Sozialforschung: Eine Einführung. Reinbek b. Hamburg: Rowohlt.

Gebert, A.J. and Kneubühler, H.-U. (2003). Qualitätsbeurteilung und Evaluation der Qualitätssicherung in Pflegeheimen: Plädoyer für ein gemeinsames Lernen. 2nd ed. Bern: Hogrefe AG.

Gelbmann, M.A. (2005). Die regionale demographische Alterung und ihre Auswirkungen im europäischen Kontext: Mit Darstellung der "Lebenszufriedenheit älterer Menschen in Heimen". Diplomarbeit Universität Klagenfurt.

Goffman, E. (1973). Asyle: Über die soziale Situation psychiatrischer Patienten und anderer Insassen. Frankfurt am Main: edition Suhrkamp.

Groves, R.M., Fowler, F.J., Couper, M.P., Lepkowski, J.M., Singer, E. and Tourangeau, R. (2004). Survey methodology. 2nd ed. Hoboken, NJ: John Wiley \& Sons.

Heinzelmann, M. (2004). Das Altenheim: immer noch eine "Totale Institution"? Eine Untersuchung des Binnenlebens zweier Altenheime. Dissertation an der sozialwissenschaftlichen Fakultät der Universität Göttingen, Göttingen.

Herold-Majumdar, A. and Behrens, J. (2012). Lebensqualität im Fokus des Qualitätsaudits in der Langzeitpflege: Der Lebensqualitäts-Index (LQ-Index) - ein “Zauberstab” mit begrenzter Wirkung. Gesundheitswesen, 74, 806-811.

Hicks, T.J. Jr (2000). What is your life like now? Loneliness and elderly individuals residing in nursing homes. Journal of Gerontological Nursing, 26(8), 15-19.

Höfler, S., Bengough, T., Winkler, P. and Griebler, R. (eds) (2015). Österreichischer Demenzbericht 2014. Vienna: Bundesministerium für Gesundheit und Sozialministerium.

Höwer, O. (2002). Pflegequalität: Was soll gemessen werden? Notwendigkeit und Möglichkeiten zur Messung pflegebeeinflussbarer Ergebnisqualität in Altenpflegeheimen. Fachhochschule Frankfurt, Studiengang Pflege, Diplomarbeit, Frankfurt am Main.

Innes, A. (2004). Die Dementia Care Mapping (DCM) Methode: Erfahrungen mit dem Instrument zu Kitwoods' person-zentriertem Ansatz. Bern: Hogrefe. 
Kane, R.A. (2001). Long-term care and good quality of life: bringing them closer together. The Gerontologist, 41(3), 293-304.

Kane, R.A. (2003). Definition, measurement, and correlates of quality of life in nursing homes: toward a reasonable practice: research, and policy agenda. The Gerontologist, 43, Special Issue II, 28-36, www.hpm.umn.edu/ltcresourcecenter/research/QOL/RAKane_Kent_lecture_2001.pdf [Accessed 14 August 2012].

Kannonier-Finster, W. and Ziegler, M. (2008). NUEVA aus sozialwissenschaftlicher Perspektive. In: J. Bernhart, W. Obwexer and K. Promberger (eds), Schlüssel zum selbstbestimmten Wohnen: Nutzerorientierte Ansätze zur Evaluation sozialer Dienstleistungen. Innsbruck: Studien Verlag.

Koller, M., Neugebauer, E.A.M., Augustin, M. Büssing, A., Farin, E., Klinkhammer-Schalke, M., Lorenz, W., Münch, K., Petersen-Ewert, C., von Steinbüchel, N. and Wieseler, B. (2009). Die Erfassung von Lebensqualität in der Versorgungsforschung: konzeptuelle, methodische und strukturelle Voraussetzungen. Gesundheitswesen, 71(12), 864-872.

Kösler, E. (2004). Bildung im vierten Alter. In: H. Brandenburg (ed.), Altern in der modernen Gesellschaft: Interdisziplinäre Perspektiven für Pflege- und Sozialberufe. Hannover: Schlütersche.

Kränzl-Nagl, R. and Maun, H. (2013). Kundenbefragungen als Seismograf für das Personalmanagement: Herausforderungen, Möglichkeiten und Grenzen. In: B. Nöbauer (ed.), Personalmanagement in der Altenbetreuung: MitarbeiterInnen gewinnen und entwickeln. Linz: Forschungsreihe "Leben im Alter".

Kränzl-Nagl, R., Lehner, M. and Prinz, T. (2019). Sozialökonomische Wirkungsevaluation in der Sozialwirtschaft: Grundlagen und Praxisbeispiele. Regensburg: Walhalla Verlag.

Kromrey, H. (2006). Empirische Sozialforschung. 11th revd ed. Stuttgart: Rowohlt.

Lage, G. (1999). Zur Befragbarkeit “alter” Menschen. Soziale Arbeit, 9, 302-306.

Lee, D., Woo, J. and Mackenzie, A.E. (2002). A review of older people's experiences with residential care placement. Journal of Advanced Nursing, 37(1), 19-27.

Müller-Hergl, C. (2008). Dementia care mapping. In: J. Hallauer (ed.), Umgang mit Demenz: Pflegequalität steigern und Pflegeverständnis sichern. Hamburg: B. Behr's Verlag.

Nienhaus, A., Westermann, C. and Kuhnert, S. (2012). Burn-out bei Beschäftigten in der stationären Altenpflege und in der Geriatrie: Ein Review zur Prävalenz. Bundesgesundheitsblatt Gesundheitsforschung - Gesundheitsschutz, 2.

Noll, H-H. (2007). Subjektives Wohlbefinden und subjektive Indikatoren der Lebensqualität: Befunde, Daten und Methoden - Eine vorläufige Bilanz. Berlin: Wissenschaftszentrum für Sozialforschung.

Noll, H-H. and Schöb, A. (2002). Lebensqualität im Alter. In: Deutsches Zentrum für Altersfragen (DZA) (ed.), Expertisen zum 4: Altenbericht der Bundesregierung. Vol. 1. Hannover: Konzepte, Forschungsfelder.

Roth, D., Rester, D. and Seeberger, B. (2009). Bewohnerbefragung in der stationären Altenhilfe eine Pilotstudie: Ergebnisse einer Zufriedenheitsbefragung und die methodische Aspekte. HeilberufeSCIENCE, 2(1), 7-12. doi:10.1007/s00058-009-1402-x.

Schnabel, E. and Schönberg, F. (2003). Qualitätssicherung und Nutzerperspektive. In: E. Schnabel and F. Schönberg (eds), Qualitätsentwicklung in der Versorgung Pflegebedürftiger: Bilanz und Perspektiven. Münster: LIT Verlag.

Schnell, R., Hill, P.B. and Esser, E. (2006). Methoden der empirischen Sozialforschung. 7th ed. Munich: Oldenbourg Verlag.

Schönberg, F. (2006). Qualitätssicherung und Nutzerperspektive in stationären Einrichtungen: Möglichkeiten und Grenzen von Bewohnerbefragungen. Vienna: Institut für Sozialarbeit und Sozialpädagogik.

Stadtler, D. (2009). Arbeitsbedingungen und Arbeitsbelastungen in der ambulanten Pflege vor dem Hintergrund des demografischen Wandels. Ruhr-Universität Bochum, Fakultät für Sozialwissenschaft, Masterarbeit, Bochum.

Van dem Knesebeck, O., David, K., Bill, P. and Hikl, R.. (2006). Aktives Altern und Lebensqualität: Evaluationsergebnisse eines WHO-Demonstrationsprojektes. Zeitschrift für Gerontologie und Geriatrie, 39, 82ff. 
Wahl, H-W. and Schneekloth, U. (2009). Der Hintergrund: Forschungen zur Lebensführung in stationären Einrichtungen. In: U. Schneekloth and H-W. Wahl (eds), Pflegebedarf und Versorgungssituation bei älteren Menschen in Heimen. Stuttgart: Kohlhammer Verlag.

Wahle, K.E. (2009). Geschichte and Alter: Altersbild und Alterserleben im historischen Wandel. Cologne: Kuratorium Deutsche Altershilfe (KDA).

Weichbold, M. (2008). Was ist eine "gute" Umfrage? SWS-Rundschau, 48(3), 342-347. Available at: http://nbn-resolving.de/urn:nbn:de:0168-ssoar-233346 [Accessed 7 June 2019].

Weichbold, M. (2009). Total survey error. In: M. Weichbold, J. Bacher and C. Wolf (eds), Umfrageforschung: Herausforderung und Grenzen. Wiesbaden: VS Verlag.

ZeSG (Zentrum für Soziales and Generationen, NÖ Landesakademie) (2010). Zufriedenheitsstudie in den niederösterreichischen Pflegeheimen der ARGE NÖ. Final report, St. Pölten. 